\title{
Classic mast cell leukemia
}

INSERM

\section{Source}

INSERM. (1999). Orphanet: an online rare disease and orphan drug data base. Classic mast cell leukemia. ORPHA:158796

Classic mast cell leukemia is a very rare, aggressive form of systemic mastocytosis characterized by abnormal growth and proliferation of neoplastic mast cells $(>20 \%)$ in the bone marrow and/or blood, as well as other tissues such as the liver, peritoneum, spleen or bones. Patients typically present with symptoms related to mast cell activation (e.g. hot flushes, fever, malaise, diarrhea, tachycardia), weight loss, anorexia, hepatosplenomegaly or, less frequently, cutaneous mastocytosis. Gastroduodenal ulcers (often complicated by hemorrhage), ascites and portal hypertension have also been reported. 